\title{
BUSCA POR SÍTIOS ALTERNATIVOS DE LIGAÇÃO NA SUPERFÍCIE DA ENZIMA TRANS-SIALIDASE DO TRIPANOSSOMA CRUZI POR DINÂMICA MOLECULAR
}

\author{
Jhonatan Deivs Barros Alves ${ }^{1}$, Gustavo de Miranda Seabra ${ }^{1 *}$ \\ ${ }^{1}$ Laboratório de Química Teórica Computacional, UFPE \\ *gustavo.seabra@ufpe.br
}

\begin{abstract}
INTRODUÇÃO
A enzima Trans-sialidase do parasita causador da Doença de Chagas, Tripanosoma cruzi, (TcTS) é uma glicosidase hidrolase $(\mathrm{GH})$, responsável por transferir unidades de ácido siálico das cé lulas do hospedeiro para o parasita, assim evadindo o sistema imunológico. O mecanismo comumente aceito para essa enzima segue um modelo "ping-pong", no qual um primeiro substrato entra no sítio ativo da enzima e transfere para a enzima um grupamento químico (no caso, um ácido siálico). Apenas depois que o restante do substrato é liberado pela enzima um segundo substrato entra e remove esse grupamento, deixando a enzima em seu estado original. Nesse mecanismo, no máximo uma molécula está ligada à enzima em cada momento, formando um intermediá rio binário.

Recentemente um mecanismo alternativo, envolvendo um intermediário ternário onde o doador e o aceitador se ligam à enzima ao mesmo tempo, foi sugerido por Oliveira et al.(OLIVEIRA et al., 2014) No entanto, as estruturas cristalinas da TCTS disponí veis mostram apenas um sítio de ligação muito estreito, de forma que um rearranjo conformacional seria necessário para acomodar ambos doador e aceitador. Nesse trabalho, estamos investigando a flexibilidade do sítio ativo da TcTS no seu mecanismo bioquímico, analisando a dinâmica do complexo.
\end{abstract}

\section{MATERIAIS E MÉTODOS}

A estrutura inicial para a enzima foi obtida do banco de dados PDB (PDBID:1S0I), e continha a trans-sialidase juntamente com o ligante sialyl lactose. Os arquivos de entrada foram gerados usando o LEaP, parte do pacote AMBERTOOLS, (CASE et al., 2014) após modificação dos nomes dos resíduos e tipos de átomos do ligante de acordo com a nomenclatura do GLYCAM. Fizemos a simulação por Dinâmica Molecular (MD) utilizando o programa SANDER, parte do pacote AMBERTOOLS 2014. (CASE et al., 2014) O sistema foi submetido a 10.000 passos de minimização de energia, seguidos de $1 \mathrm{~ns}$ de aquecimento, durante os quais o sistema foi levado gradualmente à temperatura de $310 \mathrm{~K}, 2$ ns de equilibração e 250 ns produção. O programa DOCK 6.0 foi utilizado para localizar cavidades na superfície da proteína.(ALLEN et al., 2015).

\section{RESULTADOS E DISCUSSÃO}

A estrutura do complexo estabiliza-se rapidamente na dinâmica molecular, e não se nota nenhuma mudança significativa após cerca de 35 ns de simulação, o que pode ser observado no gráfico de RMSD (Figura 1). Na Figura 2 temos a informação da presença de bolsões próximos ao sítio ativo da enzima, dando possibilidade de um mecanismo diferente do que é aceito atualmente.
TcTS with Sialyllactose

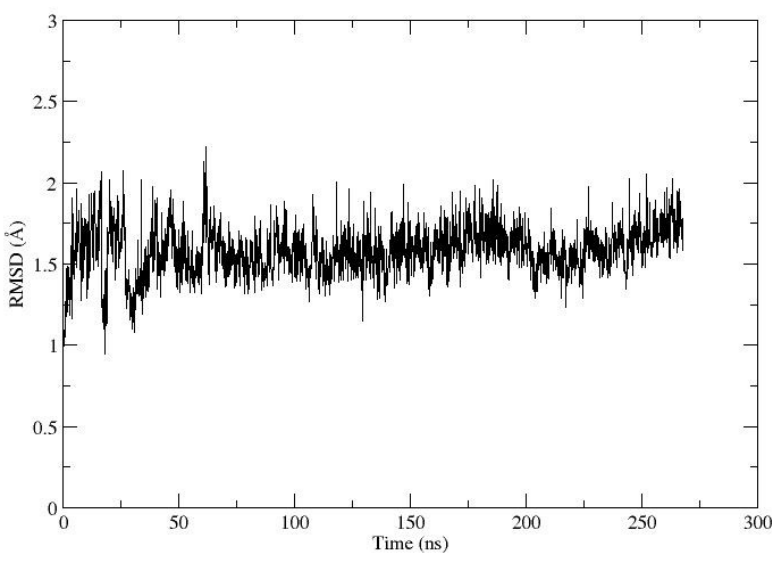

Figura 1. Gráfico RMSD da enzima-ligante

A Figura 2 mostra o resultado da busca por cavidades usando o programa sphgen, parte do pacote UCSF DOCK. Com este programa, foi possível gerar as esferas dentro de clusters. As esferas são geradas na ausência do ligante, de forma que o sítio ativo deve naturalmente ser ocupado por esferas. Dentre os vários clusters gerados, apenas 1 mostrou cavidades próximas ao sítio ativo da enzima. Esse cluster, chamado de cluster 1, contém 75 esferas, que na Figura 2 foram redimensionadas para que sejam mostradas apenas as que estão a uma distância maior que $3 \AA$ de forma a eliminar a região já ocupada pelo ligante. 0 programa popula com esferas as regiões de cavidades na superfície da proteí na. Assim, as esferas na figura simbolizam cavidades desocupadas, regiões que podem acomodar outro ligante.

É possível notar pelo menos 3 cavidades separadas, que oferecem possibilidades de interação próximas ao sítio ativo, onde a enzima pode interagir com um segundo ligante. Essas cavidades próximas ao sítio ativo (Figura 2) são indícios de que pode existir um mecanismo diferente, onde a enzima trans-sialidase interage com o ligante sialil-lactose e ao mesmo tempo tenha interação com uma segunda lactose, pertencente ao organismo receptor do ácido siá lico, formando assim um complexo ternário como foi sugerido anteriormente.

Os resultados sugerem a possibilidade da abertura de um segundo sítio de ligação após a ligação da sialil-lactose, permitindo a ligaçã o do segundo ligante. Os próximos passos incluem: 


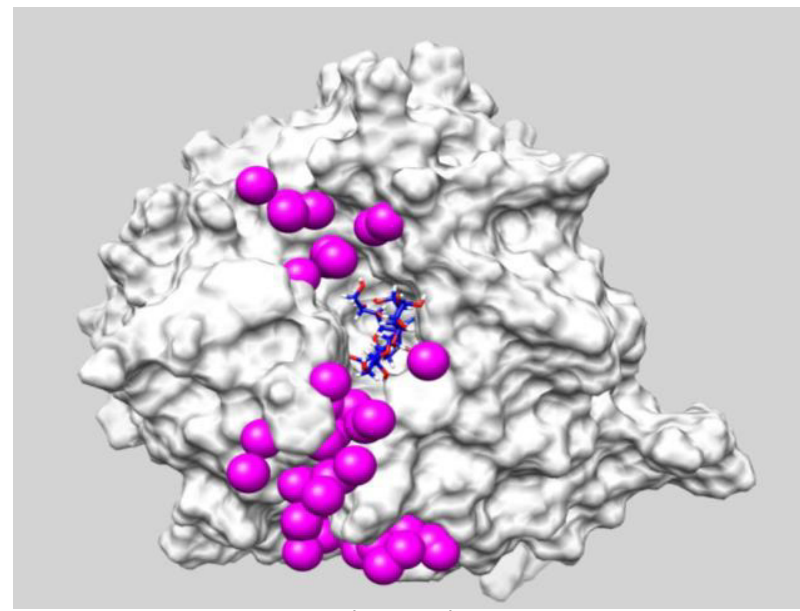

Figura 2. Busca por esferas próxima ao sítio ativo.

i) Acompanhar a abertura da cavidade no curso da dinâmica molecular

ii) Agrupamento das estruturas da trajetória em grupos (clusters) que representam as diferentes conformaç ões da proteína

iii) Geração de estruturas representativas de cada cluster;

iv) Busca por sítios de ligação em cada cluster de estruturas, de forma semelhante à descrita acima

v) Docking com uma lactose com nas cavidades obtidas em cada cluster, para verificar a possibilidade de ligação

vi) Cálculos de QM/MM para verificar a energética da reação de transferência do ácido siálico no mecanismo alternativo

\section{CONCLUSÕES}

Esses resultados indicam a possibilidade do novo mecanismo para a reação enzima-substrato para essa enzima. A próxima etapa do trabalho envolve acompanhar a abertura do sítio alternativo no decorrer da simulação, utilizar docking molecular para localizar um novo substrato formando um complexo ternário com a enzima e sialil-lactose, e finalmente simular a reação de transferência com o novo mecanismo para comparar com o mecanismo comumente aceito.

\section{REFERÊNCIAS}

ALLEN, William J. et al. DOCK 6: Impact of new features and current docking performance. Journal of Computational Chemistry, v. 36, n. 15, p. 1132-1156, 2015.

CASE, D.A. et al. AMBER 14. . [S.l.]: University of California, San Francisco. 2014

OLIVEIRA, Isadora a. et al. Evidence of ternary complex formation in Trypanosoma cruzi trans-sialidase catalysis. Journal of Biological Chemistry, v. 289, n. 1, p. 423-436, 2014. 